\title{
Reproductive Health Knowledge of Married Women from Farming Families
}

\author{
Nasreen Banu* and K. Yashoda
}
AICRP-H.Sc (All India Coordinated Research Project-Home Science), PGRC, PJTSAU (Professor Jayashankar Telangana State Agricultural University), Rajendranagar, Hyderabad-30, Telangana State, India

*Corresponding author

\section{A B S T R A C T}

\section{Keywords \\ Reproductive health, Intervention programme, Married women \\ Article Info \\ Accepted: \\ 12 October 2018 \\ Available Online: \\ 10 November 2018}

Present study was taken up to find out the Knowledge levels of the Married women in the adopted villages of Maheshwarammandal, RR district, Hyderabad with regard to Reproductive health issues. Seventy five Married women (without children) formed the sample for the present study. Checklist was developed to find out the Knowledge levels of Married women. Based on the results, Knowledge based Intervention programmes were organized. Impact assessment showed significant improvement in the Knowledge levels of the sample, reflecting the effectiveness of the Intervention programme.

\section{Research facts}

Currently, there seem to be a low level of access to quality reproductive health information and services especially to some vulnerable groups such as Young Married Women. There has been increasing interest in research involving Young Married women in recent years in developing countries.

Reasons for this increasing interest include an increasing recognition on the part of researchers of young women sexuality and reproductive health needs, given along with the rate of sexually transmitted infections
(STI), including HIV. In addition, although information, education, and communication (IEC) programs have been successful in increasing young people's knowledge about reproductive health issues, they have been much less successful in changing behavior. There is much demand, in particular from Young married women, for reproductive health information, and information about contraceptive use. Despite adults in general not feeling comfortable with this topic, a consensus in many countries has been built that young people need more information, skills, and services concerning sexual and reproductive health. 


\section{Introduction}

The world over, women are fighting for control over their health and their bodies-for their basic human rights. When women are guaranteed their reproductive health, everyone wins. At the most basic level, access to family planning - including contraception and abortion - lets a woman decide if, when and how many children to have, immediately benefiting not only her health and wellbeing, but that of her family as well. Women with access to contraception tend to be healthier, more educated and more economically productive.

Protecting women's reproductive health is not only is it a human right, but the positive impact of a woman's autonomy over her reproductive health choices is clear. It increases her decision-making power, placing her in a stronger position overall to demand other rights - such as access to education and employment - for herself, her family and her community.

Despite the critical importance of women's reproductive health to development, reproductive health threats are still the leading cause of illness and death among women of childbearing age around the world. It's not enough to declare women's reproductive rights as a human right. We must act - to increase awareness of the benefits of reproductive health, to expand access to family planning services, and more.

Young women lack understanding and ability to apply their knowledge to their attitudes and behaviors. For instance with contraception, they not only do not know how to use contraceptives but also cannot access services. The level of knowledge about contraceptives is not high and young person's knowledge cannot be utilized. In addition, their attitudes are not positive, with most expressing negative attitudes towards premeditated sexual activities (Khong, 1998)

A universal reason why adults have trouble assisting youth to adopt healthy lifestyle is that adults themselves may be uncertain about how to discuss issues related to intimacy and sexuality. They themselves lack knowledge and life skill about sexuality and reproductive health. No one has talked to them about these issues, so they have no experiences in transmitting such knowledge. Many parents express desire to learn more so they can better educate their children (Population Council, 1997).

Family education plays a special role compared to other sources of family information. Other sources while providing a valuable service to adolescents, may not be the most appropriate for adolescents, both because the information provided tends to be very superficial and also because adolescents are probably less likely to pay attention to information provided through institutional sources than where information are provided through primary sources such as the family. However, different family members play different roles in communication. The mother is more likely to discuss sexual issues than the father (Population Council). Some girls prefer to speak with their grandmother because they are afraid their mother will scold them (Pham, 1997, Population Council, 1997).

\section{Operational definition}

\section{Married women}

A woman who has a husband living and not divorced;

\section{Knowledge}

Knowledge is a familiarity, awareness, or understanding of someone or something, such 
as facts, information, descriptions, or skills, which is acquired through experience or education by perceiving, discovering, or learning.

According to Webster's dictionary, knowledge is 'the fact or condition of knowing something with familiarity gained through experience or association'. In practice, though, there are many possible, equally plausible definitions of knowledge.

A frequently used definition of knowledge is "the ideas or understandings which an entity possesses that are used to take effective action to achieve the entity's goal(s).

\section{Intervention}

An intervention is a combination of programme elements or strategies designed to produce behavior changes or improve health status among individuals or an entire population.

\section{Reproductive health}

Reproductive health refers to the diseases, disorders and conditions that affect the functioning of the male and female reproductive systems during all stages of life. Reproductive health is a state of complete physical, mental and social well-being, and not merely the absence of reproductive disease or infirmity. Reproductive health deals with the reproductive processes, functions and system at all stages of life.

\section{Materials and Methods}

Sample was identified from the adopted villages (5) of Maheshwarammandal, RR District, Hyderabad, through field survey and focused group interviews with the help of the AWWs, ANMs, and Women Self-help Group leaders in the village.

\section{Criteria for sample selection}

Women who were married and living with their husband

Women who were married and without children

\section{General objective}

Promoting Reproductive health Knowledge among Married Rural Women

\section{Specific objectives}

To find out the demographic profiles of the Selected sample

To find out the Knowledge levels of the Selected sample with regard to Reproductive health

To develop suitable IEC material for promoting Reproductive health among the selected sample

To conduct Knowledge based Intervention programme to the selected sample

To assess the impact of the Intervention programme on the Knowledge levels of the selected sample

\section{Research strategy adopted}

In order to achieve the above objectives, Knowledge based Intervention programmes were organized for the Married women, using the developed IEC material.

\section{Research tools details}

SES scale developed by Aggrawal et al., (2005) was used to find out the SES of the Rural families. Scoring was given as per the norms provided in the manual. It is a 
standardized scale, used to assess the family background information of the individuals, which includes parameters like educational and occupational status of parents, number of siblings, material possession, kind of locality, presence of farm animals, land holdings, number of earning members in the family etc. The scale categorizes the sample on: Upper High; High; Upper middle; Lower middle; Poor and Very poor Socio Economic Status.

Reproductive health awareness checklist was developed by AICRP-CD, Hyd Unit, (2017) to find out the Knowledge levels of Married women with regard to Reproductive health issues. The Reliability Value of the checklist is: 0.81. The checklist comprises of 5 dimensions:

\section{Pre-conception health}

It is the First dimension and has 26 statements. It measures the knowledge levels of the sample in the following 4 areas: Preparation for Parenthood (7 statements); Factors that Boost Preconception Health (8 statements); Preparedness for pregnancy (5 statements); and Preconception Behaviours (6 statements).

\section{Reproductive health problems}

It is the Second dimension and has 31 statements. It measures the knowledge levels of the sample in the following 4 areas: Menstrual problems (9 statements); Menstrual hygiene practices (6 statements); Potential risks to health due to poor menstrual hygiene (4 statements); Gynecological problems (12 statements).

\section{Family planning}

It is the Third dimension and has 17 statements. It measures the knowledge levels of the sample in the following 3 areas: Family Planning Methods (5statements); Purpose of following Family planning methods (4statements); Contraceptive related problems (8statements).

\section{Sexually transmitted diseases}

It is the Fourth dimension and has 36 statements. It measures the knowledge levels of the sample in the following 5 areas: Awareness about HIV/AIDS and related problems (8 statements); Awareness about RTI/STD related problems (11 statements); Awareness about transmission of HIV / AIDS (9 statements); Preventive methods for HIV/AIDS (3 statements); Preventive methods for RTI/STD (5 statements).

\section{General}

It is the Fifth dimension and has 30 statements. It measures the knowledge levels of the sample in the following 3 areas: Services Related to Reproductive Health (10 statements); Awareness about marital laws \& legal rights (9 statements); Awareness about Reproductive rights (11 statements).

There are all together 140 statements (all 5 dimensions).Each statement is arranged on 3 point scale i.e. aware is marked as 3; aware but not sure 2; Not sure as 1 . The total scores were further grouped as Low, Average and high. Higher the score, higher is the level of Knowledge in that particular dimension.

\section{Results and Discussion}

\section{Demographic data on married women}

There were 961 married women from the selected clusters of adopted villages, Maheshwarammandal, RR district.

Out of 961 married women, 8\% (80) were without children and 75 formed the sample for the present study. 
Table.1 Age wise distribution of the sample $(\mathrm{N}=75)$

\begin{tabular}{|l|l|l|l|}
\hline $16-19$ yrs & $20-25$ yrs & $26-30 y r s$ & $31-35 y r s$ \\
\hline N \& \% & N \& \% & N \& \% & N \& \% \\
\hline $42(56 \%)$ & $33(44 \%)$ & --- & --- \\
\hline
\end{tabular}

Table.2 Education wise distribution of the sample $(\mathrm{N}=75)$

\begin{tabular}{|l|l|l|l|}
\hline $\begin{array}{l}\text { Primary } \\
\text { school }\end{array}$ & $\begin{array}{l}\text { Secondary } \\
\text { school }\end{array}$ & Inter & $\begin{array}{l}\text { Degree } \\
\text { Continuing }\end{array}$ \\
\hline N \& \% & N \& \% & N \& \% & N \& \% \\
\hline $\begin{array}{l}11 \\
(15 \%)\end{array}$ & 30(40\%) & $17(22 \%)$ & $11(15 \%)$ \\
\hline
\end{tabular}

Table.3 Occupation wise distribution of the sample $(\mathrm{N}=75)$

\begin{tabular}{l|l|l|l|}
$\begin{array}{l}\text { House } \\
\text { wife } \\
\text { N \& \% }\end{array}$ & $\begin{array}{l}\text { Fully } \\
\text { involved in } \\
\text { agriculture } \\
\text { N \& \% }\end{array}$ & $\begin{array}{l}\text { Partially } \\
\text { involved in } \\
\text { agriculture } \\
\text { N \& \% }\end{array}$ & $\begin{array}{l}\text { Petit } \\
\text { business }\end{array}$ \\
\hline $\mathbf{1 5}(20 \%)$ & $37(49 \%)$ & $20(27 \%)$ & $3(4 \%)$
\end{tabular}

Table.4 Socio economic status of the sample $(\mathrm{N}=75)$

\begin{tabular}{|c|c|c|}
\hline $\begin{array}{l}\text { Socio economic } \\
\text { status } \\
\text { classification }\end{array}$ & Score & $\begin{array}{l}\text { Married women } \\
\text { without children } \\
(\mathrm{N}=75)\end{array}$ \\
\hline Upper High & $>76$ & ------- \\
\hline High & $61-75$ & $3(4 \%)$ \\
\hline Upper middle & $46-60$ & $12(16 \%)$ \\
\hline Lower middle & $31-45$ & $42(56 \%)$ \\
\hline Poor & $16-30$ & $18(24 \%)$ \\
\hline Very poor & $<15$ & ------- \\
\hline
\end{tabular}


Table.5 Reproductive health knowledge scores of married women (without children) - Pretest scores

\begin{tabular}{|c|c|c|c|c|}
\hline S.no & $\begin{array}{l}\text { Reproductive Health } \\
\text { awareness dimensions }\end{array}$ & Category & Score & $\begin{array}{l}\text { Married women } \\
\text { without children } \\
\text { N=75 (No \& \%) }\end{array}$ \\
\hline \multirow[t]{3}{*}{$\mathbf{A}$} & \multirow{3}{*}{$\begin{array}{l}\text { Preconception Health } \\
\text { (26 statements) }\end{array}$} & High & $53-78$ & $18(24 \%)$ \\
\hline & & Average & $27-52$ & $44(59 \%)$ \\
\hline & & Low & $<26$ & $13(17 \%)$ \\
\hline \multirow[t]{3}{*}{$\mathbf{B}$} & \multirow{3}{*}{$\begin{array}{l}\text { Reproductive health } \\
\text { problems ( } 30 \\
\text { statements) }\end{array}$} & High & $61-90$ & $25(33 \%)$ \\
\hline & & Average & $31-60$ & $35(47 \%)$ \\
\hline & & Low & $<30$ & $15(20 \%)$ \\
\hline \multirow[t]{3}{*}{$\mathbf{C}$} & \multirow{3}{*}{$\begin{array}{l}\text { Family planning(17 } \\
\text { statements) }\end{array}$} & High & $35-51$ & $15(20 \%)$ \\
\hline & & Average & $18-34$ & $43(57 \%)$ \\
\hline & & Low & $<17$ & $17(23 \%)$ \\
\hline \multirow[t]{3}{*}{$\mathbf{D}$} & \multirow{3}{*}{$\begin{array}{l}\text { Sexually transmitted } \\
\text { diseases(36 statements) }\end{array}$} & High & $73-108$ & $25(33 \%)$ \\
\hline & & Average & $37-72$ & $35(47 \%)$ \\
\hline & & Low & $<36$ & $15(20 \%)$ \\
\hline \multirow[t]{3}{*}{$\overline{\mathbf{E}}$} & \multirow[t]{3}{*}{ General (30 statements) } & High & $61-90$ & $12(16 \%)$ \\
\hline & & Average & $31-60$ & $38(51 \%)$ \\
\hline & & Low & $<30$ & $25(33 \%)$ \\
\hline
\end{tabular}

Table.6 Reproductive health knowledge scores of married women (without children) - Post assessment scores

\begin{tabular}{|c|c|c|c|c|}
\hline S.no & $\begin{array}{l}\text { Reproductive Health } \\
\text { awareness dimensions }\end{array}$ & Category & Score & $\begin{array}{l}\text { Married women } \\
\text { without children } \\
\text { N=75 (No \& \%) }\end{array}$ \\
\hline \multirow[t]{3}{*}{$\mathbf{A}$} & \multirow{3}{*}{$\begin{array}{l}\text { Preconception Health (26 } \\
\text { statements) }\end{array}$} & High & $53-78$ & $42(56 \%)$ \\
\hline & & Average & $27-52$ & $28(37 \%)$ \\
\hline & & Low & $<26$ & $5(7 \%)$ \\
\hline \multirow[t]{3}{*}{ B } & \multirow{3}{*}{$\begin{array}{l}\text { Reproductive health } \\
\text { problems (30 statements) }\end{array}$} & High & $61-90$ & $37(49 \%)$ \\
\hline & & Average & $31-60$ & $33(44 \%)$ \\
\hline & & Low & $<30$ & $5(7 \%)$ \\
\hline \multirow[t]{3}{*}{ C } & \multirow{3}{*}{$\begin{array}{l}\text { Family planning(17 } \\
\text { statements) }\end{array}$} & High & $35-51$ & $40(53 \%)$ \\
\hline & & Average & $18-34$ & $32(43 \%)$ \\
\hline & & Low & $<17$ & $3(4 \%)$ \\
\hline \multirow[t]{3}{*}{$\mathbf{D}$} & \multirow{3}{*}{$\begin{array}{l}\text { Sexually transmitted } \\
\text { diseases( } 36 \text { statements) }\end{array}$} & High & $73-108$ & $36(48 \%)$ \\
\hline & & Average & $37-72$ & $32(43 \%)$ \\
\hline & & Low & $<36$ & $7(9 \%)$ \\
\hline \multirow[t]{3}{*}{$\mathbf{E}$} & \multirow[t]{3}{*}{ General (30 statements) } & High & $61-90$ & $36(49 \%)$ \\
\hline & & Average & $31-60$ & $28(37 \%)$ \\
\hline & & Low & $<30$ & $11(14 \%)$ \\
\hline
\end{tabular}


Table.7 Reproductive health knowledge scores (Pre \& Post) of married women (without children) $(\mathrm{N}=75)$

\begin{tabular}{|c|c|c|c|c|c|c|c|c|c|}
\hline \multirow[t]{2}{*}{ Dimensions } & \multirow{2}{*}{$\begin{array}{l}\text { Sub- } \\
\text { Dimensions }\end{array}$} & \multicolumn{2}{|c|}{ Raw scores } & \multicolumn{2}{|l|}{ Mean } & \multicolumn{2}{|l|}{ SD } & \multirow{2}{*}{$\begin{array}{l}\text { Mean } \\
\text { diff } \\
\text { (P1-P) }\end{array}$} & \multirow[t]{2}{*}{ T values } \\
\hline & & (P) & (P1) & (P) & (P1) & (P) & (P1) & & \\
\hline \multirow{5}{*}{$\begin{array}{l}\text { Pre-conception } \\
\text { Health } \\
\text { (includes } 4 \\
\text { dimensions) }\end{array}$} & $\mathrm{A}(\mathrm{PP})$ & 930 & 1058 & 24.47 & 27.84 & 3.36 & 3.48 & 3.37 & $2.72 * *$ \\
\hline & $\mathrm{B}(\mathrm{PCH})$ & 1027 & 1167 & 27.03 & 30.71 & 3.59 & 3.75 & 3.41 & $9.60 * *$ \\
\hline & $\mathrm{C}(\mathrm{PP})$ & 630 & 738 & 16.58 & 19.42 & 2.18 & 2.39 & 2.84 & $1.23 * *$ \\
\hline & $\mathrm{D}(\mathrm{PB})$ & 813 & 944 & 21.39 & 24.84 & 3.01 & 3.11 & 3.45 & $7.58 * *$ \\
\hline & Total & 3400 & 3907 & 89.47 & 102.81 & 11.37 & 11.80 & 13.34 & $5.36 * *$ \\
\hline \multirow{5}{*}{$\begin{array}{l}\text { Reproductive } \\
\text { health } \\
\text { problems } \\
\text { (includes } 4 \\
\text { dimensions) }\end{array}$} & A (MP) & 1192 & 1231 & 31.37 & 32.39 & 4.66 & 4.40 & 1.02 & $0.06 * *$ \\
\hline & B (MHP) & 817 & 871 & 21.5 & 22.92 & 3.36 & 3.05 & 1.42 & $1.84 * *$ \\
\hline & $\mathrm{C}(\mathrm{PR}-\mathrm{MH})$ & 543 & 591 & 14.29 & 15.55 & 2.17 & 2.13 & 1.26 & $1.02 * *$ \\
\hline & $\mathrm{D}(\mathrm{GP})$ & 1630 & 1791 & 42.89 & 47.13 & 6.67 & 6.44 & 4.24 & $1.25^{* *}$ \\
\hline & Total & 4182 & 4484 & 110.05 & 118 & 15.67 & 14.23 & 7.95 & $1.06 * *$ \\
\hline \multirow{4}{*}{$\begin{array}{l}\text { Family } \\
\text { planning } \\
\text { (includes } 3 \\
\text { dimensions) }\end{array}$} & A (FPM) & 660 & 768 & 17.37 & 20.21 & 2.77 & 2.60 & 2.84 & $4.94 * *$ \\
\hline & B (PFPM) & 523 & 624 & 13.76 & 16.42 & 2.35 & 2.20 & 2.66 & $1.14 * *$ \\
\hline & $\mathrm{C}(\mathrm{CP})$ & 993 & 1215 & 26.13 & 31.97 & 3.84 & 4.22 & 5.84 & $1.05^{* *}$ \\
\hline & Total & 2176 & 2607 & 57.26 & 68.60 & 8.14 & 8.08 & 11.34 & $1.02 * *$ \\
\hline \multirow{6}{*}{$\begin{array}{l}\text { Sexually } \\
\text { transmitted } \\
\text { diseases } \\
\text { (includes } 5 \\
\text { dimensions) }\end{array}$} & A (HIV/AIDS) & 1038 & 1076 & 27.31 & 28.31 & 3.77 & 4.04 & 2.0 & $0.04 \mathrm{NS}$ \\
\hline & B (RTI/STD) & 1367 & 1434 & 35.97 & 37.74 & 4.54 & 4.77 & 1.77 & $0.07 \mathrm{NS}$ \\
\hline & $\begin{array}{l}\mathrm{C} \\
\text { HIV/AIDS })\end{array}$ & 1229 & 1325 & 32.34 & 34.87 & 5.07 & 5.0 & 2.53 & $4.33^{* *}$ \\
\hline & $\begin{array}{l}\mathrm{D} \text { (PM- } \\
\text { HIV/AIDS) }\end{array}$ & 426 & 462 & 11.21 & 12.16 & 1.99 & 1.91 & 0.95 & $0.01 \mathrm{NS}$ \\
\hline & $\begin{array}{l}\mathrm{E} \quad(\mathrm{PM} \\
\mathrm{RTI} / \mathrm{STD})\end{array}$ & 701 & 757 & 18.45 & 19.92 & 3.04 & 3.02 & 1.47 & $0.01 \mathrm{NS}$ \\
\hline & Total & 4761 & 5054 & 125.29 & 133 & 16.97 & 16.63 & 7.71 & $1.19 * *$ \\
\hline \multirow{4}{*}{$\begin{array}{ll}\text { General } & \\
\text { (includes } & 3 \\
\text { dimensions) }\end{array}$} & A (RHS) & 1209 & 1317 & 31.81 & 34.66 & 4.85 & 5.77 & 2.85 & $1.84 * *$ \\
\hline & B (M\&LR) & 1129 & 1340 & 29.71 & 35.26 & 5.16 & 5.44 & 5.55 & $5.36 * *$ \\
\hline & $\mathrm{C}(\mathrm{RR})$ & 1399 & 1686 & 36.81 & 44.37 & 6.79 & 7.17 & 7.56 & $1.09 * *$ \\
\hline & Total & 3737 & 4343 & 98.34 & 114.29 & 16.06 & 17.33 & 15.95 & $2.12 * *$ \\
\hline
\end{tabular}

Note: ** at $1 \%$ level of significance 


\section{Abbreviations}

\begin{tabular}{|l|l|l|l|l|l|}
\hline $\begin{array}{l}\text { 1. Pre- } \\
\text { conception } \\
\text { Health }\end{array}$ & $\begin{array}{l}\text { A:Preparation for } \\
\text { Parenthood }\end{array}$ & $\begin{array}{l}\text { B:Factors that } \\
\text { Boost } \\
\text { Preconception } \\
\text { Health }\end{array}$ & $\begin{array}{l}\text { C:Preparedness } \\
\text { for pregnancy }\end{array}$ & $\begin{array}{l}\text { D:Preconcept } \\
\text { ion } \\
\text { Behaviours }\end{array}$ \\
\hline $\begin{array}{l}\text { 2. } \\
\text { Reproducti } \\
\text { ve health }\end{array}$ & $\begin{array}{l}\text { A:Menstrual } \\
\text { problems }\end{array}$ & $\begin{array}{l}\text { B:Menstrual } \\
\text { hygiene practices }\end{array}$ & $\begin{array}{l}\text { C:Potential risks to } \\
\text { health due to poor } \\
\text { menstrual hygiene }\end{array}$ & $\begin{array}{l}\text { D:Gynecologi } \\
\text { cal problems }\end{array}$ & --------- \\
\hline $\begin{array}{l}\text { 3. Family } \\
\text { planning }\end{array}$ & $\begin{array}{l}\text { A:Family Planning } \\
\text { Methods }\end{array}$ & $\begin{array}{l}\text { B:Purpose of } \\
\text { following Family } \\
\text { planning methods }\end{array}$ & $\begin{array}{l}\text { C:Contraceptive } \\
\text { related problems }\end{array}$ & ---------- & --------- \\
\hline 4. STD & $\begin{array}{l}\text { A:Awareness about } \\
\text { HIV/AIDS } \\
\text { \&related problems }\end{array}$ & $\begin{array}{l}\text { B:Awareness } \\
\text { about RTI/STD } \\
\text { related problems }\end{array}$ & $\begin{array}{l}\text { C:Awareness about } \\
\text { transmission of } \\
\text { HIV / AIDS }\end{array}$ & $\begin{array}{l}\text { D:Preventive } \\
\text { methods for }\end{array}$ & $\begin{array}{l}\text { E:Preventive } \\
\text { methods for } \\
\text { RTI/STD }\end{array}$ \\
\hline 5. General & $\begin{array}{l}\text { A:Services Related } \\
\text { to Reproductive } \\
\text { Health }\end{array}$ & $\begin{array}{l}\text { B:Awareness } \\
\text { about marital laws } \\
\text { \& legal rights }\end{array}$ & $\begin{array}{l}\text { C:Awareness about } \\
\text { Reproductive } \\
\text { rights }\end{array}$ & ---------- \\
\hline
\end{tabular}

\section{Educational Posters}

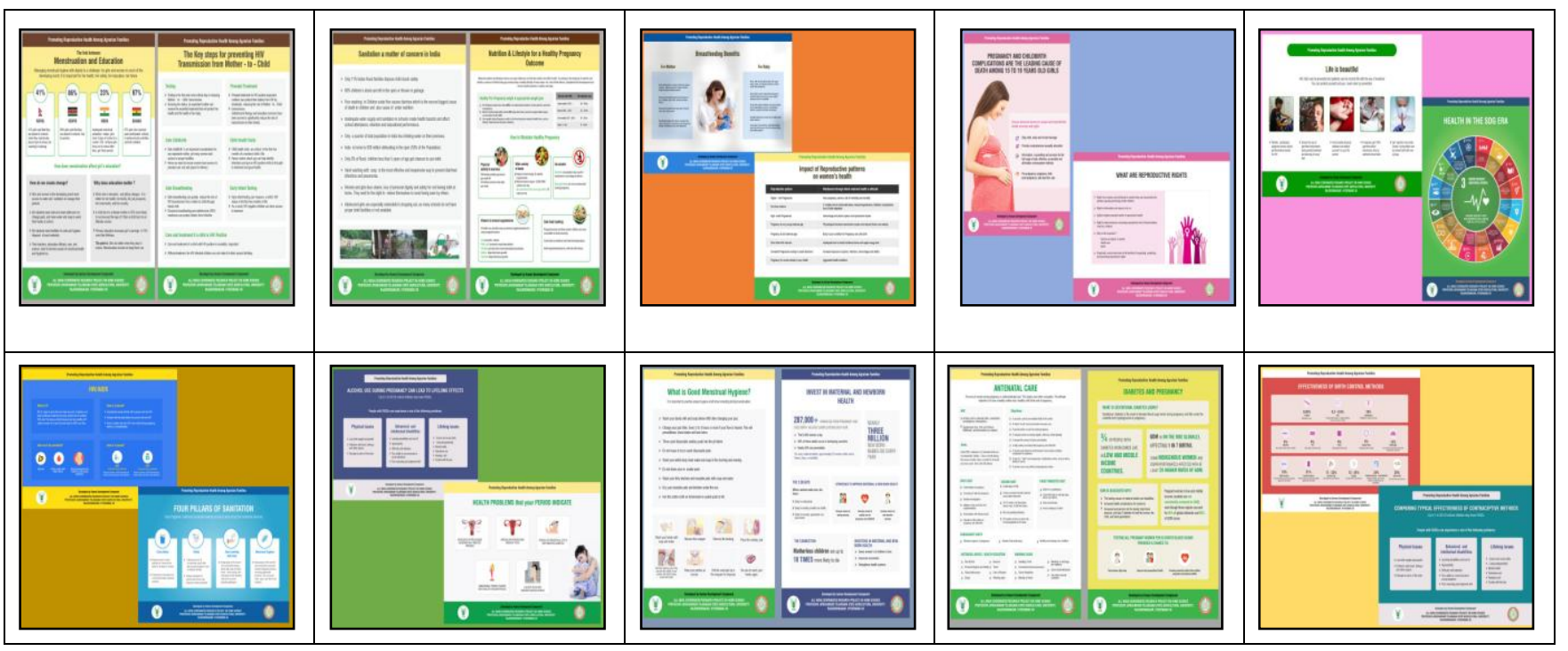




\section{Capacity building programmes}
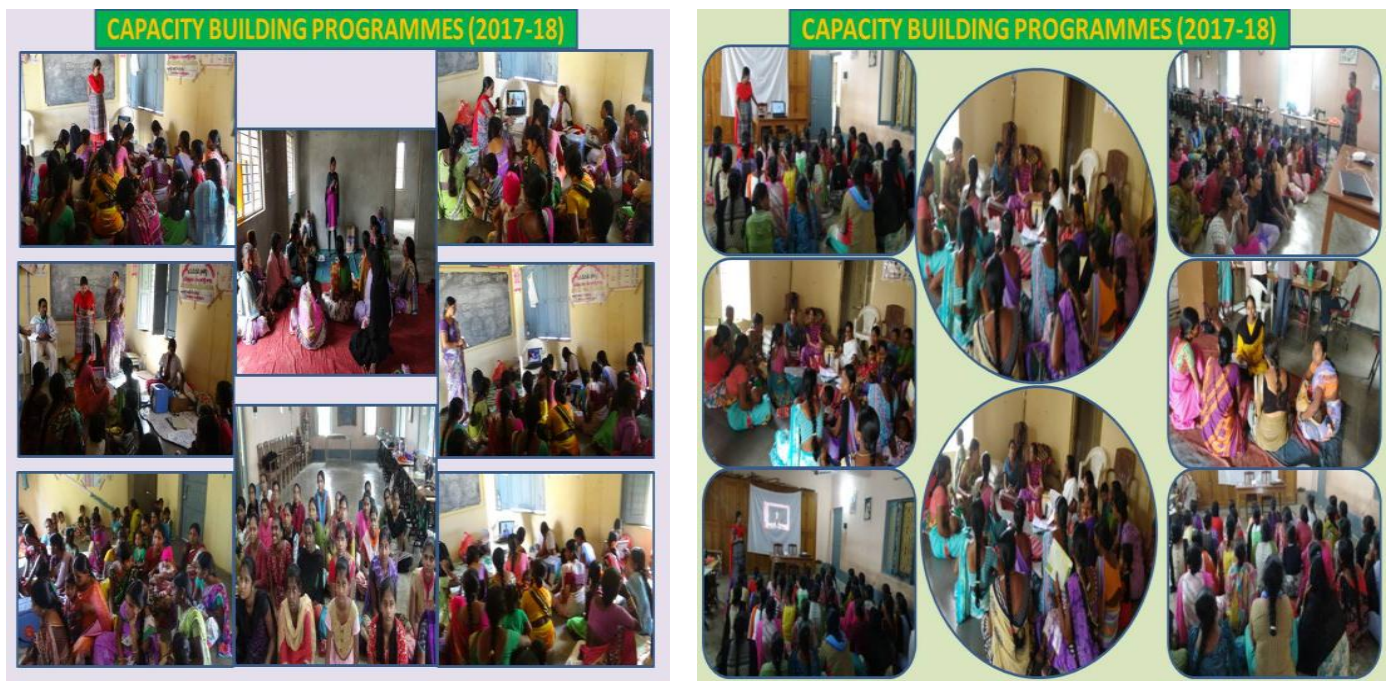

Reproductive Health knowledge scores of Married women (without children) - Dimension \& category wise

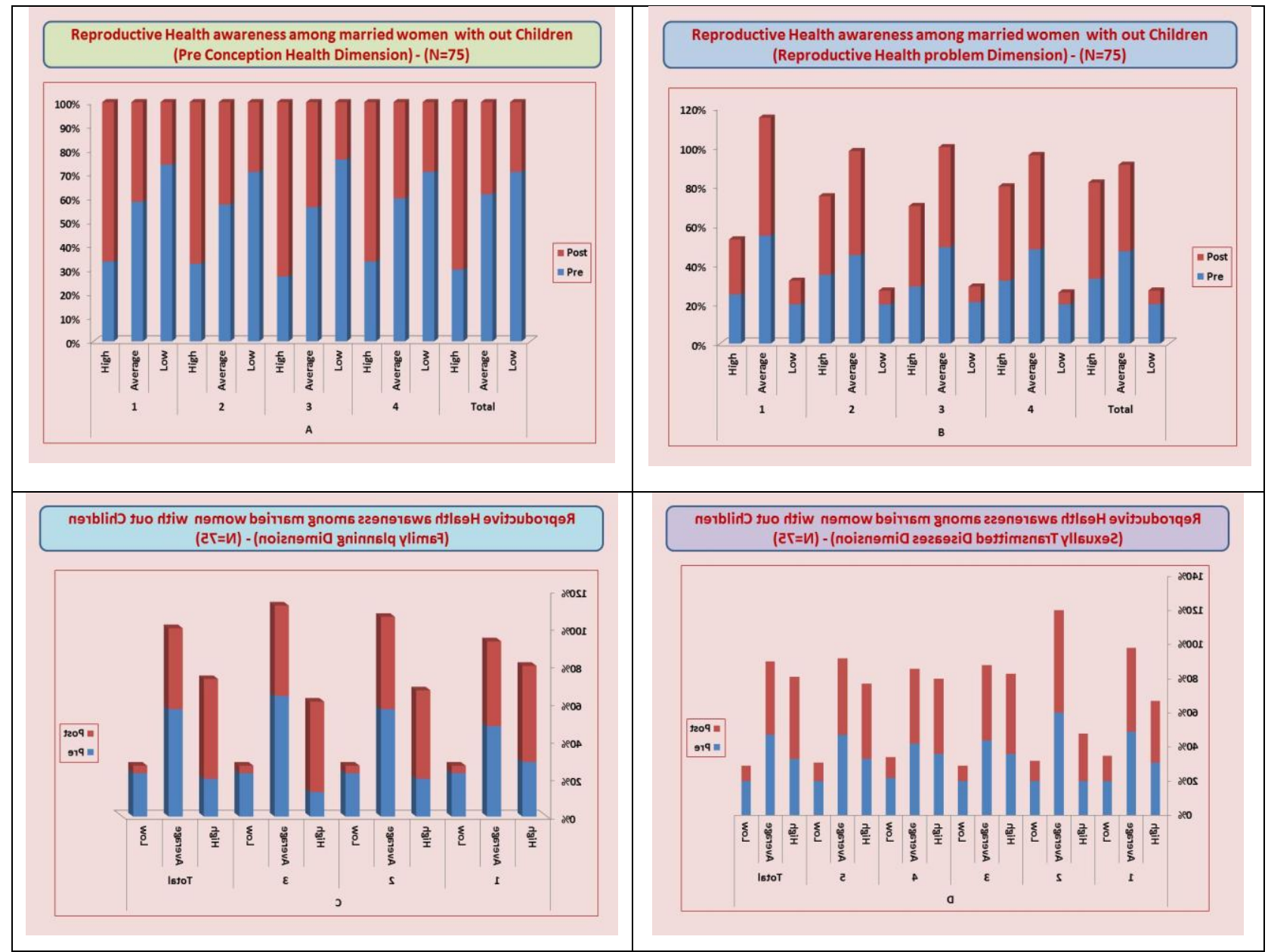



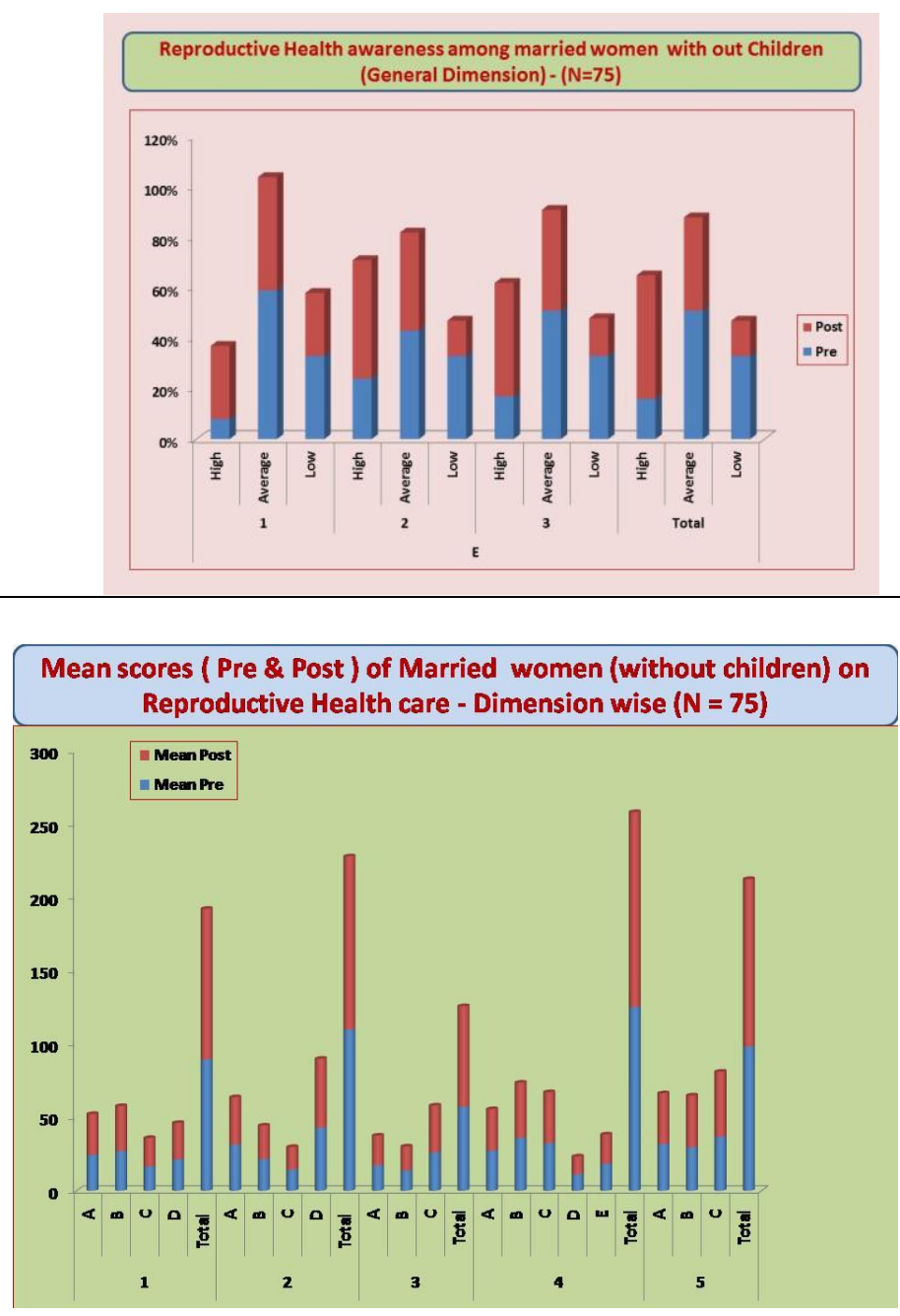

The table 1 depicts the Age wise distribution of the sample (Married women without children). Out of the total sample 75 , slightly more than half of (59\%) were in the age range of 16-19 yrs and remaining $44 \%$ were in the age group of 20-25 yrs.

The table 2 depicts the Education wise distribution of the sample (Married women without children). Out of the total sample 75, less than half of (40\%) completed secondary school; 22\% completed Inter; $15 \%$ completed Primary school and $15 \%$ were pursuing their degree.

The table 3 depicts the Occupation wise distribution of the sample (Married women without children). Out of the total sample 75, almost half of (49\%) the sample were fully involved in agriculture; $27 \%$ were partially involved in agriculture; $20 \%$ were housewives and only $4 \%$ were running petit business.

The table 4 depicts the Socio Economic Status of the sample (Married women without children). Out of the total sample 75, more than half of $(56 \%)$ the sample were in lower middle income level; $24 \%$ were in poor economic status; $16 \%$ were in upper middle income level and only $4 \%$ were in high income group.

The table 5 traces the pretest scores of married women with regard to Reproductive 
Health. The Self structured Checklist covers 5 dimensions.

With regard to Preconception Health dimension, out of 75 , more than half $(59 \%)$ of the sample obtained Average scores; $24 \%$ obtained High scores and 17\% obtained Low scores.

With regard to Reproductive health problem dimension, less than half (47\%) of the sample obtained Average scores; 33\% obtained High scores and $20 \%$ obtained Low scores.

With regard to Family planning dimension, more than half $(57 \%)$ of the sample obtained Average scores; $23 \%$ obtained Low scores and $20 \%$ obtained High scores.

With regard to Sexually transmitted diseases dimension, less than half (47\%) of the sample obtained Average scores; 33\% obtained High scores and $20 \%$ obtained Low scores.

With regard to General dimension, half (51\%) of the sample obtained Average scores; 33\% obtained Low scores and 16\% obtained High scores.

\section{Planning \& preparing educational material}

Based on the bench mark issues and preassessment results, videos, brochures, leaflets, resource books and educational posters were planned / developed on issues concerning Reproductive Health for conducting Awareness programmes for Married women.

Educational posters mainly focused on: Adolescent Reproductive health; Balanced diet during Pregnancy; Birth control facts; Benefits of Breast feeding; Comprehensive nutrition; Condom use; Contraception choices; Healthy pregnancy; HIV prevention; Transmission of AIDs; Transmission of STI/ RTI; Reproductive rights; Reproductive problems; Reproductive health; Antenatal care; Immunization schedule; Menstrual hygiene; Menstrual problems; Menstrual education; Neonatal health; Sanitary napkin; STI symptoms

Some of the intervention strategies used for promoting Reproductive Health Knowledge among the sample was: group exercises, role plays, open ended stories, Brain storming, Group activities, Situation analysis, Case studies, Responding to real life situations and Group discussions etc.

\section{Conducting programmes on reproductive health care}

Knowledge based Capacity building programmes (25) were conducted for married women from the adopted villages on issues concerning Reproductive Health care.

\section{Impact of knowledge based intervention}

The table 6 traces the post-test scores of married women with regard to Reproductive Health Knowledge.

With regard to Preconception Health dimension, out of 75 , more than half $(56 \%)$ of the sample obtained High scores; 37\% obtained Average scores and only 7\% obtained Low scores.

With regard to Reproductive health problem dimension, less than half (49\%) of the sample, obtained High scores; 44\% obtained Average scores and only $7 \%$ obtained Low scores.

With regard to Family planning dimension, more than half $(53 \%)$ of the sample obtained High scores; $43 \%$ obtained Average scores and only $4 \%$ obtained Low scores.

With regard to Sexually transmitted diseases dimension, less than half (48\%) of the sample 
obtained High scores; $43 \%$ obtained Average scores and only $9 \%$ obtained Low scores.

With regard to General dimension, less than half $(49 \%)$ of the sample obtained High scores; 37\% obtained Average scores and only $14 \%$ obtained Low scores.

The table 7 presents the Pre \& Posttest (Raw scores, Means, SD and T values) Scores of Married women (without children) with regard to Sub-dimensions under Reproductive Health Care. The table shows the progressive increase in the total raw scores across pre-test to post-test, along with the increase in the mean differences, which shows the impact of intervention programme. $\mathrm{T}$ values between the two means of pre-test and post-test was found to be highly significant, as the calculated values were found to be greater than the tabulated value. The results reflect the effectiveness of Intervention programmes on the Knowledge levels of Married women (without children) with reference to Reproductive Health.

Awareness of family planning practices is limited among Young Married women in rural areas; because of this they are prone with unsafe abortions. Also in Rural areas are still ignorant of prevention of STI and HIV/AIDS, so they are also at risk of contacting this deadly disease. The freedom to discuss about reproductive health in Rural areas is still limited. Parents should be helped to deliberately break the culture of silence and discuss sexual matters freely with their children. Educational planners at all levels should see the need to include reproductive health education in the formal academic curriculum.

\section{References}

Aggrawal, et al., 2005. Indian Journal of Community Medicine Vol. 30, No. 4, October-December, 2005

Khong, 1998. Reproductive Health for Young Girl. By National Committee for Population and Family Planning (NCPFP), and German Technical Cooperation (GTZ). In Reproductive and Sexual Health for Adolescents Seminar in Quynhon city, Binhdinh Province, Vietnam.

Pham and Ta Thi Thanh Thuy, 1997. Reproductive Knowledge, Attitudes and Practices among Adolescent Students in HoChiMinh City. By Population Council and Center of Medical Sociology. In Youth Reproductive Health: Report of the Seminar in Hanoi. Population Council Vietnam, 1997. A Study of Vietnamese Youth's Decision making for Health and HIV/AIDS Prevention in Kiengiang, Quangninh Provinces. Hanoi. Population Council Vietnam.

\section{How to cite this article:}

Nasreen Banu and Yashoda, K. 2018. Reproductive Health Knowledge of Married Women from Farming Families. Int.J.Curr.Microbiol.App.Sci. 7(11): 1377-1388.

doi: https://doi.org/10.20546/ijcmas.2018.711.160 